American Journal of Applied Sciences 9 (4): 579-583, 2012

ISSN 1546-9239

(C) 2012 Science Publications

\title{
Socioeconomic Impact on Farmers in Malaysia: A Case Study on Integrated Agricultural Development Project
}

\author{
${ }^{1}$ Nor Diana Mohd Idris, ${ }^{1}$ Chamhuri Siwar, \\ ${ }^{2}$ Basri Abdul Talib and ${ }^{2}$ Madeline Berma \\ ${ }^{1}$ Institute for Environment and Development (LESTARI), \\ ${ }^{2}$ School of Economics, Faculty of Economics and Management, \\ University Kebangsaan Malaysia, 43600 Bangi, Selangor Darul Ehsan, Malaysia
}

\begin{abstract}
Problem statement: Integrated Agricultural Development Project (IADP) is a platform for rural socioeconomic improvement. This initiative has raised the income of farmers by creating a large scale fruits producer in Sarawak. Therefore, the objective of this study was to identify the direct impact of the agricultural development project on socioeconomic improvement in the Samarahan area. Approach: This study involved 14 villages and is located in the Mid-Samarahan and Upper Samarahan areas. A total of 220 households were interviewed during December 2005-February 2006 to collect information on yield and household income. The paired t-test analysis showed that the project had a positive impact on in-farm and other incomes of farmers. Results: It was also revealed that the poverty level of Sarawak state was reduced from the poverty line, from $77 \%$ in $1986-19.5 \%$ in 2005 . The percentage of hard core poverty fell from $30.9 \%$ in $2000-6.4 \%$ in 2005. Conclusion: The project was generally implemented as an appraisal to increase the incomes of rural population through fruit cultivation as a main economic activity. It was concluded that this project is efficient as a tool to combat poverty and improved the socioeconomic level and income generating activities among the rural community.
\end{abstract}

Key words: Poverty, agricultural activity, income generation, IADP

\section{INTRODUCTION}

Sarawak state has one of the highest poverty rates in Malaysia Malaysia, 2010 since independence especially in the rural area. Rural area and poor communities almost a sysnonym for the agricultural sector (Kalantari et al., 2008). They usually have few resources under their control and thus the possibility on in situ resources exploitation is often an issue of survival (Glasmeier and Farrigan, 2003). In order to achieve sustainable livelihood in rural communities, poverty reduction through, s, sustain the economic viability of farm operation, satisfy human food and fibre needs and enhance the quality of life for farmers and society as a whole (Murad et al., 2008). Therefore, sustainable rural development in the agricultural sector often receives attention in the planning agenda of poverty eradication program in Malaysia through various government programs (Hashim, 1996). IADP programme is an anti-poverty program that is designed to improve the socioeconomic level of rural farmers which was adapted from the concept of Integrated Rural Development (IRD) strategy that is designed to attack the causes and consequences of rural poverty in an integrated and comprehensive manner. According to the Centre on Integrated Rural Development for Asia and the Pacific (CIRDAP, 2007), this strategy is also to emphasize the administrative and physical preparation which is imperative at both the international and national level. It is aimed at extending the benefit of development to the poorest among those who seek livelihood in the rural areas. It is to provide physical and economic structures and social amenities such as rural roads, irrigation and drainage, schools, health, water and electricity and agricultural support services such as credit, input supplies, marketing, research and extension through a coordinated and integrated manner by various development agencies. IADP's approach in Malaysia was designed to revitalize and rehabilitate insitu or existing agricultural areas that are faced with problems of low productivity, poverty, structural and institutional problem such as the size of land, crop management system and idle land problem (Ragayah, 2009). Samarahan IADP has adopted several strategies designed to increase productivity, maximize farmers' income and modernize farm operation and was

Corresponding Author: Nor Diana Mohd Idris, Institute for Environment and Development (LESTARI),

University Kebangsaan Malaysia, 43600 Bangi, Selangor Darul Ehsan, Malaysia 
established since 1986 covering an area of 86,170h. It consists of 3 districts namely by Kuching, Siburan, Samarahan and Serian having 13,200 families or 66,000 households. The plants that have been undertaken in the area are cultivated pineapple, fruits (lime, mango, jackfruit, honeydew and banana) and also short term crops such as ginger, maize, yam, vegetables and papaya. This project was carried out in groups or individually. The main objective of IADP Samarahan is to make this area as the most important food production area in Sarawak as well as in the socio-economic level of farmers. It is consistent with the objective of the National Agriculture Policy 3 (NAP3) which is to maximize income through the optimal use of resources. Therefore, this study was conducted to identify the impact of the IADPs to improve the well-being in terms of reducing the poverty, increasing income and livelihood strategies' patterns among farmers. For that reasons, Poverty Line Income (PLI) will be used in this study to look at the incidence of poverty and the patterns of income for a clearer micro picture of the current situation of farmers involved in IADPs. According to Malek and Usami (2009), diversification as an increase in the number of household income components. In order to diversified portfolio of activities and the ability of social support in their struggle to survive and at the same time seeks to improve living standards, it also usually depends on livelihood of farmers from his own resources and capabilities, environmental and economic condition and policies and programs undertaken by the institution (Ur-Rehman, 2008). This diversity provides an avenue for rural communities to survive in a changing environment as well as face great pressures from market forces like migration among Bangladeshi peoples (Alam et al., 2011). The study also focuses on livelihood strategies of those who depend on agriculture to participate in the institutions responsible for IADPs to make a difference in their lives and to achieve sustainability of livelihood. Thus, according to Krueger and Lindhal (2001), often the strategy depends on the person's life based on his own resources and capabilities, the environment, current socioeconomic situation and policies and programs undertaken by the institution.

\section{MATERIALS AND METHODS}

Study area: This study is employed into two study areas with the aim to compare socio-economic status of the farmers between before and after participation in IADP projects. Three districts were randomly selected which are Samarahan, Siburan and Padawan Districts which comprise of 14 villages. A total of 220 farmer households that participate actively and have IADPs agricultural yields for the purpose of calculating the total household income were chosen. Therefore, the villages selected under this study have similar characteristics with respect to topography, demography, economic, social and cultural conditions. The map of Samarahan IADPs and the study areas are shown in Fig. 1.

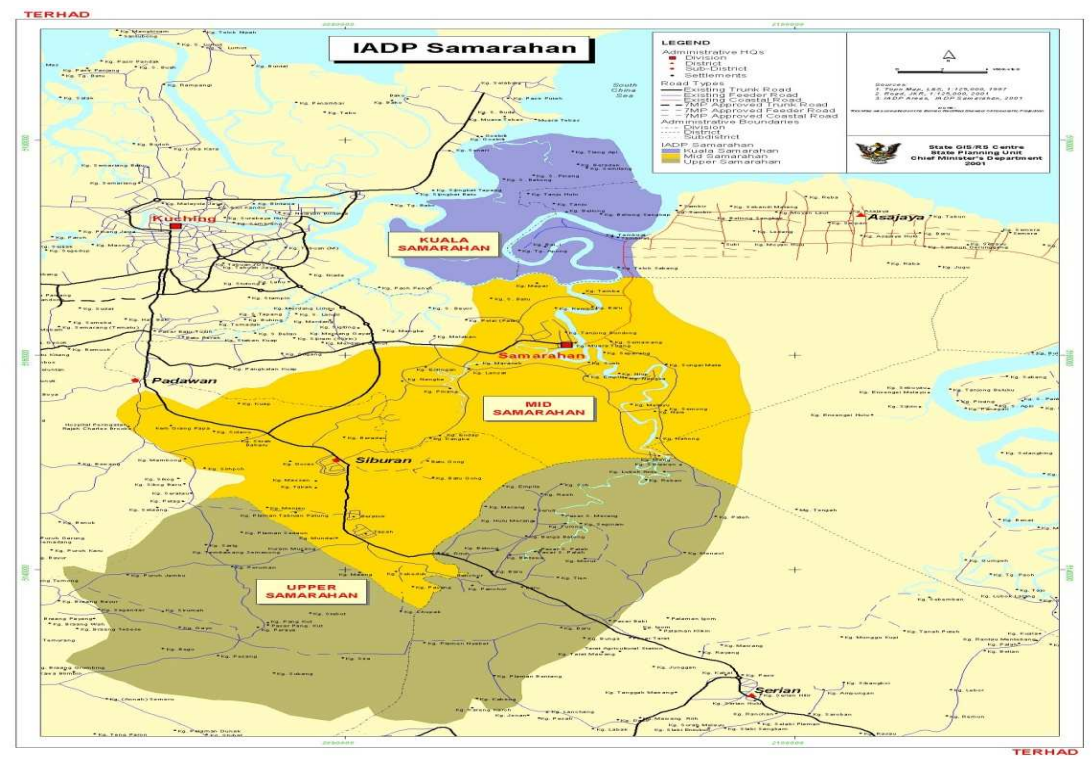

Fig. 1: Map of Samarahan IADP 
Sampling methods: This study is highly dependent upon the survey method to derive accurate information from respondents. The direct face-to-face interview is employed in this study. Data was collected through interviews from the selected samples of IADP among rural farmers who are actively participating in this programme. In this study, sampling design was followed by 'random sampling' method. The methods used in carrying out impact studies have been adapted as recommended by World Bank which compares the situation before and after the project is established (Baker, 2001). The data was collected by Statistical analysis using paired t-test was conducted to evaluate differences between group means sources of farmer income through IADPs intervention. This study utilized the Statistical Package for Social Sciences (SPSS) version 17 to analyze the data.

\section{RESULTS}

Table 1 shows that the monthly average in-farm, off-farm and other incomes of farmers are estimated at RM586 (US\$154), RM540 (US\$142) and RM201 (US\$53) which contribute to about 44, 41 and $15 \%$ respectively of their average total family income for the year 2000. Compared to the year 2005, contribution of all types of farmers' income is about 59, 24 and 17\%, respectively, out of the total family income of about RM1962 (US\$516). It shows that the performance of sources of in-farm income increased by $96.0 \%$ followed by other incomes with a contribution of about $66 \%$, whereas the off-farm income declined by $11.4 \%$. Overall, during the period of participation in IADPs, the total income had increased by $48 \%$ with an average of $9.5 \%$ per annum.

A paired samples t-test was carried out between before and after IADPs intervention. The test revealed that there was a highly statistically significant difference between before and after intervention, $t(219)$ $=9.43, \mathrm{p}<0.01$. The mean income after intervention $(M=1962 \mathrm{SD}=3775)$ was higher than the mean income before intervention $(\mathrm{M}=1328 \mathrm{SD}=3528)$.

For each income category, this study found that the average in-farm income sources have a highly statistically significant difference, $\mathrm{t}(219)=7.99, \mathrm{p}<$ 0.01 . This shows a rejection of $\mathrm{H}_{0}$ and the increase of total in-farm income of RM563 is proof of the positive impact of IADPs by managing to increase farmers' agricultural income sources. This result is similar for other types of income as indicated by an increase of RM133 and proven statistically significant with t(219) the researcher and trained enumerators using a pretested interview schedule and the period was from December 2005-February 2006.

Data analysis: After collecting the results of the survey, all the data were coded directly on to a questionnaire and then entered into a personal computer. Several analyses of the data have been carried out as the core of this study. Simple descriptive statistics such as sums, means, ranges, percentages and frequency distributions are used to analysis primary data for this study. $=3.54 \mathrm{p}<0.01$. The mean income after IADPs' intervention $(\mathrm{M}=334 \mathrm{SD}=451)$ was higher than the mean income before, as shown by $(M=201 \mathrm{SD}=569)$. On the other hand, off-farm income sources show that there were no statistically significant difference between before and after intervention of IADPs $t(219)$ $=-0.79$.

Table 2 shows the income distribution of farmers are separately by hard core poor, poor and non-poor category. For the non-poor income category, there is an increase of $33.3 \%$ and for those earning RM5001RM10000 and above, there is an increase of $1.4 \%$. Meanwhile, the income of farmers within the range of RM1501-RM5000 has increased by $2.1 \%$. The highest contribution of farmers' income is in the range of RM1501-RM3000 with an increase of $19.1 \%$ and the farmers in the income range of RM3001-RM5000 remains the same. The farmers, who managed to escape the poverty line, are $2.7 \%$. Therefore, based on the PLI used in 2005, the result shows that the incidence of poverty has decreased by $34.0 \%$ from $53.6 \%$ in 2000 to $19.6 \%$ in 2005 .

Table 3 shows that the majority of respondents who joined the program are full-time farmers with about $160(72.7 \%)$. This was followed by those who work as laborers with 23 respondents $(10.5 \%)$, general workers with $12(5.5 \%)$ and teachers with $6(2.7 \%)$. The rest are respondents who work as village chief, security guards, carpenters and independent/no salary work which contributed $4.5 \%$ respectively. While those working as government servants such as clerks, laboratory assistants, assistant accountants and Headman are about $1(0.5 \%)$ respectively.

The majority of respondents are fulltime farmers at $123(55.9 \%) .59$ respondents $(26.8 \%)$ make farming as a sideline job, followed by business at about 16 respondents $(7.3 \%)$, carpenters were $5(2.3 \%)$, the Imam at the mosque and the contractors with a total of $4(1.81 \%)$. Engaged as miners and fishermen were 3 respondents $(1.36 \%)$ and as a security guard with just $1(0.5 \%)$. 
Am. J. Applied Sci., 9 (4): 579-583, 2012

Table 1: Monthly average income of farmers

\begin{tabular}{|c|c|c|c|c|c|c|c|}
\hline \multirow[b]{2}{*}{ Sources of income } & \multicolumn{2}{|l|}{2000} & \multicolumn{2}{|l|}{2005} & \multicolumn{2}{|l|}{ Changes (RM) } & \multirow[b]{2}{*}{$\mathrm{t}$-value } \\
\hline & Average $*(\mathrm{RM})$ & $(\%)$ & Average $*(\mathrm{RM})$ & $(\%)$ & $(+/-)$ & $(\%)$ & \\
\hline In-farm & 586 (US\$154) & 44 & 1149 (US\$302) & 59 & $563.00(\mathrm{US} \$ 148)$ & 96.0 & $7.99^{\mathrm{a}}$ \\
\hline Off-farm & 540.00 (US\$142) & 41 & 478 (US\$125) & 24 & 62 (US\$16) & -11.4 & $-0.79^{\mathrm{ns}}$ \\
\hline Others & 201 (US\$53) & 15 & 334 (US\$87) & 17 & $133.00(\mathrm{US} \$ 35)$ & 66.0 & $3.54^{\mathrm{a}}$ \\
\hline Total of income & 1328 (US\$ 86) & 100 & 1962 (US\$516) & 100 & 634.00 (US\$166) & 48.0 & \\
\hline
\end{tabular}

*: 1 \$US = RM3.8, during the period of data collection; ${ }^{\text {a,ns }}$ : Significant at $99 \%$, not significant at $\alpha<0.10$

Table 2: Income distribution of respondent

\begin{tabular}{|c|c|c|c|c|}
\hline Income categories & Income level & $2000(\%)$ & $2005(\%)$ & $+/-(\%)$ \\
\hline Hardcore poor & $<$ RM482 & $68(30.9)$ & $14(6.4)$ & -24.50 \\
\hline Poor & RM482-RM765 ${ }^{1}$ & $50(22.7)$ & $29(13.2)$ & -9.50 \\
\hline \multirow[t]{6}{*}{ Non-poor } & RM766-RM1000 & $26(11.8)$ & $32(14.5)$ & 10.90 \\
\hline & RM1001-RM1500 & $40(18.2)$ & $58(26.4)$ & \\
\hline & RM 1501-RM3000 & $24(10.9)$ & $66(30.0)$ & 21.00 \\
\hline & RM3001- RM5000 & $6(2.7)$ & $12(5.5)$ & \\
\hline & RM5001-RM10 000 & $4(1.8)$ & $7(3.2)$ & 1.40 \\
\hline & > RM10 001 & $2(0.9)$ & $2(0.9)$ & \\
\hline
\end{tabular}

${ }^{1}$ Poverty Line Income (PLI), Sarawak in 2005 was RM765 for the household size of 4.8 persons (or RM159.37 per person) (Economic Planning Unit, 2006). Households whose incomes is half of the income poverty line (about RM482 and below) are categorized as poor families. Source: Field survey, 2005

Table 3: Distribution of main and part time job of respondent

\begin{tabular}{|c|c|c|c|c|}
\hline \multirow[b]{2}{*}{ Types of jobs } & \multicolumn{2}{|l|}{ Full time } & \multicolumn{2}{|l|}{ Part time } \\
\hline & Before unit (\%) & After unit (\%) & Before unit (\%) & After unit (\%) \\
\hline Farmer & $132(60.0)$ & $160(72.7)$ & $67(30.5)$ & $59(26.8)$ \\
\hline Fisherman & $4(1.81)$ & - & $3(1.36)$ & $3(1.36)$ \\
\hline Labourer & $38(17.2)$ & $23(10.5)$ & $5(2.27)$ & $2(0.90)$ \\
\hline Business & $2(0.90)$ & - & $16(7.27)$ & $16(7.27)$ \\
\hline Contractor & $1(0.50)$ & - & $2(0.90)$ & $4(1.81)$ \\
\hline Government servant & $28(12.7)$ & $25(11.4)$ & - & - \\
\hline Private sector & $11(5.00)$ & $7(3.18)$ & $5(2.27)$ & $4(1.81)$ \\
\hline Others * & $4(1.81)$ & $5(2.27)$ & $11(5.00)$ & $9(4.09)$ \\
\hline Total & 220 & 220 & $109 * *$ & $97 * *$ \\
\hline
\end{tabular}

Note: *: Others include mechanic, craftsman home and others which are not mentioned specifically. $* *$ : Those are focus on full time farmers.

Sources: Field survey 2005

\section{DISCUSSION}

Impact on household income and poverty: Income is an important indicator to measure the individual standard of living (Ferdousi et al., 2011). There are three types of sources of farmers income in IADP Samarahan area which consist of in-farm, off-farm and other incomes. The ultimate goal of the project by the government is an effort to make Sarawak a major food producer and improve the living standards of farmers with a targeted income of RM 1500 per month.

This proves that the implementation of IADPs have positive impacts on increasing the overall income of farmers in the study areas. It was also revealed that the poverty level of Sarawak state was reduced from the poverty line, from $77 \%$ in $1986-19.5 \%$ in 2005.

It can be concluded that IADPs were effective in enhancing farmers' income. In facts, IADPs are not effective in increasing off-income of farmers which consists of salaries or wages and small scale businesses among household farmers. This shows that there are not many people who are involved in these activities and statistically does not contribute to changes in the level of farmers income in the study areas. Mean while the intervention of IADPs is reveals a decrease of $6.8 \%$ per annum for the incidence of poverty and it shows be able to improve the socioeconomic level of rural farmers in Sarawak in contexs of agricultural sector. It is seem like finding study on microcredit programme by Ferdousi et al. (2011) shows that positive impacts to changing and improving livelihood status of poor family in contexs of financial loans.

Impact on livelihoods strategy: There is no significant difference in percentage compared to the situation before and after the respondents participated in the IADPs project. The higher participating farmers were involved in agricultural activities shows that they have a strong background in this field compared to other 
activities and it also attract many farmers to participate in the project activities.

\section{CONCLUSION}

The study shows that the IADPs have a significant impact on socioeconomic livelihoods of rural farmers. The IADPs reduce the incidence of poverty, increase income of the rural farmers and attract opportunities for job development in their lives and families. The present study shows that the incidence of poverty has decreased by $34.0 \%$ from $53.6 \%$ in 2000 to $19.6 \%$ in 2005 . This shows a decrease of $6.8 \%$ per annum due to socioeconomic interventions in developing IADPs rural farmers. The finding of the study suggests that the rural farmers, after joining the IADPs were experienced and motivated to undertake the creation of economic activities based on agriculture or agro-based industry as it is known locally. This is the way to manipulate factors of production such as labor resources, agricultural inputs, natural resources and physical facilities that are available to achieve sustainable livelihoods with agriculture as a long-lasting source of income. It is shown that IADPs provide opportunities of income generation that help to improve the socioeconomic level as well as their livelihoods. It is concluded that this project is efficient as a tool to combat poverty and improve the socioeconomic level and income generating activities among rural communities.

\section{ACKNOWLEDGEMENT}

The researchers are grateful to UKM project code IRPA 08-02-02-0018 EA281 Linking Environment and Rural Poverty: Formulating Resources Use, Governance and Sustainable Policies that supported this study. We are also thankful to respondents for providing valuable information and data. We wish to thank all the staffs of Samarahan Integrated Agricultural Development Project, Sarawak, Division of Services and Industry Development, Ministry of Agriculture and Agro-Base Industry of Malaysia, for their kind cooperation and permission to carry out the field works under this project areas.

\section{REFERENCES}

Alam, F., S. Chamhuri, T. Basri and R. Islam, 2011. Impacts on international migration and remittances growth. Am. J. Enviorn. Sci., 7: 20-25. DOI: 10.3844/ajessp.2011.20.25

CIRDAP, 2007. Centre on Integrated Rural Development for Asia and the Pacific. CIRDAP.

Ferdousi, A., S. Chamhuri and H.I.N. Aini, 2011. Contribution of microcredit for improving family income of the rural women in panchagarh district of Bangladesh. Aust. J. Basic Applied Sci., 5: 360-366.

Glasmeier, A.K. and T.L. Farrigan, 2003.. Poverty, Sustainability and the culture of despair: Can sustainable development strategies support poverty alleviation in america's most environmentally challenged communities? Annal Am Acad Political Soc. Sci., 590: 131-149. DOI: 10.1177/0002716203257072

Hashim, N.N.M. 1996. Agricultural Development Planning in Malaysia. Dewan Bahasa and Pustaka. Kuala Lumpur, Malaysia.

Baker, J.L., 2001. Evaluating the impact of development projects on poverty: A handbook for practitioners. The World Bank Group.

Kalantari, K., S.F. Hossien, A. Ali, Q. Iraj and C. Shala, 2008. Major challenge of iranian rural communities for achieving sustainable development. Am. J. Agric. Biol. Sci., DOI: 10.3844/ajabssp.2008.724.728

Krueger, A.B. and M. Lindhal, 2001. Education for Growth: Why and for whom? J. Econ. Literature, 39: 1101-1136.

Malek, A.M. and K. Usami, 2009. Determinants of Non-farm Income Diversification in Developed Villages of Bangladesh. Am. J. Econ. Bus. Admin., 1:141-149. DOI: 10.3844/ajebasp.2009.141.149

Murad, Md.W., Nik H.N Mustapha and S. Chamhuri. 2008. Review of Malaysian Agricultural Policies with Regards to Sustainability. Am. J. Enviorn. Sci., 4: 608-614. DOI: 10.3844/ajessp. 2008. 608.614

Ragayah, H.M.Z. 2009. Growth with Equality a Reality and Hope. Universiti Kebangsaan Malaysia. 